\title{
Immunoquantitative Analysis of Human Carnitine Palmitoyltransferase I and II Defects
}

\author{
FRANCE DEMAUGRE, JEAN-PAUL BONNEFONT, CLAUDE CEPANEC, JASPER SCHOLTE, \\ JEAN-MARIE SAUDUBRAY, AND JEAN-PAUL LEROUX \\ Laboratoire de Biochimie, INSERM U75, Faculté de Médecine Necker [F.D., C.C., J.-P.L.], and Clinique de \\ Génétique Médicale, Hopital des Enfants Malades [J.-P.B., J.-M.S.], 75015 Paris, France; and Department of \\ Biochemistry I, Erasmus University, Rotterdam, The Netherlands [J.S.]
}

\begin{abstract}
Carnitine palmitoyltransferase deficiency realizes two distinct clinical forms. We previously showed and confirmed in the present work that CPTII (identified as the carnitine palmitoyltransferase activity assayable in detergent conditions) is decreased in the muscular form whereas it is unaffected and CPTI is decreased in the hepatic form. The antibody previously prepared against human liver mitochondrial CPTII recognizes the same enzyme in muscle, liver, and fibroblasts. Immunoprecipitation experiments were performed in fibroblasts from patients with the muscular and hepatic forms of the defect. As compared with controls, cell lines from two patients with the hepatic form of the defect did not exhibit any qualitative nor quantitative abnormality of cross-reacting material, whereas cell lines from two patients with the muscular form of the defect exhibited a decreased amount of cross-reacting material. These data suggest that CPTII deficiency could result from a decreased production of protein. The amount of cross-reacting material in the two sets of patients only correlates with CPTII activity, which is decreased in the muscular presentation and unaffected in the hepatic form. These results strengthen the hypothesis of distinct proteins supporting CPTI and CPTII activities. (Pediatr Res 27: 497-500, 1990)
\end{abstract}

\section{Abbreviations}

CPT, carnitine palmitoyltransferase

CPTI, carnitine palmitoyltransferase I

CPTII, carnitine palmitoyltransferase II

CRM, cross-reacting material

CPT is involved in the mitochondrial oxidation of long-chain fatty acids. Their transport across mitochondrial membranes is thought to be accomplished through the sequential action of CPTI and CPTII $(1,2)$. In situ, both enzymes display very different kinetic and regulatory properties (3-5). Moreover, it was reported that CPTI activity, unlike CPTII activity, was rapidly lost in the solubilized form with detergents $(6,7)$. The basis of these differences is not clear. One possibility is that CPTI and CPTII are distinct proteins $(8-10)$. Others have proposed that the two enzymes are identical (11-13). Their different behavior while membrane-associated would be ascribed to differences in their physical environments.

In human pathology, CPT deficiency realizes two different

Received October 7, 1988; accepted January 8, 1990.

Correspondence: Dr. France Demaugre, INSERM U75, Faculté de Médecine Necker Enfants Malades, 75730 Paris Cedex 15, France.

Supported by a grant from l'Association Francaise contre la Myopathie. clinical presentations: one with muscular (14), the other with hepatic (15) symptoms. The analysis of CPT activities of fibroblasts from patients with muscular and hepatic forms of the deficiency showed that CPTI deficiency was involved in the hepatic form, whereas CPTII defect was evidenced in the muscular form (16).

CPT from human liver was purified from mitochondrial membranes solubilized with Triton X100 according to procedures (17) that are thought to select (6-9) the protein that supports CPTII activity, and antibodies against this protein were raised in rabbits (Demaugre F, Cepanec C, Leroux JP, unpublished data).

In our study, we show that immune serum recognized a similar protein in liver, skeletal muscle, and fibroblasts. In fibroblasts of patients with CPTII defect (muscular form), a decreased amount of protein was recognized by the immune serum, whereas no qualitative nor quantitative abnormality was observed in fibroblasts of patients with CPTI deficiency (hepatic form).

\section{MATERIALS AND METHODS}

Fibroblasts from controls and CPT-deficient patients were cultured as previously described (18). Cell lines A and B were from patients with hepatic presentation $(15,16)$ and cell lines $C$ and D from patients with muscular presentation. Muscular CPT deficiency of these patients was previously described. Human livers were from kidney transplantation donors. Livers were removed within $30 \mathrm{~min}$ after circulation arrest, immediately frozen in solid $\mathrm{CO}_{2}$, and stored at $-80^{\circ} \mathrm{C}$ before use.

CPT activity. CPT activity was assayed by the measurement of palmitoyl $\mathrm{L}-\left(\right.$ methyl $\left.{ }^{14} \mathrm{C}\right)$ carnitine formation from palmitoyl $\mathrm{CoA}$ and $\mathrm{L}-\left(\mathrm{methyl}{ }^{14} \mathrm{C}\right)$ carnitine. Assays I and II were performed as previously described (16) on fibroblast homogenates. Assay I, performed in nondetergent conditions, was carried out with 110 $\mu \mathrm{M}$ palmitoyl CoA complexed with $1 \%$ albumin, $550 \mu \mathrm{M} \mathrm{L-}$ carnitine and, if noted, $50 \mu \mathrm{M}$ malonyl CoA. CPT activity, assayable in detergent conditions, was measured by assay II conducted without albumin, with $1 \mathrm{mM}$ palmitoyl-D-carnitine, $40 \mu \mathrm{M}$ palmitoyl $\mathrm{CoA}$, and $1 \mathrm{mM}$ L-carnitine. CPT activity assayable in detergent conditions was also measured in the $100000 \mathrm{~g}$ supernatant of fibroblasts, muscle, and liver solubilized with $1 \%$ Tween 20 and $500 \mathrm{mM} \mathrm{KCl}$. Incubation mixture was similar to that of assay I except that albumin was omitted.

Immunoinhibition experiments. Aliquots of $100000 \mathrm{~g}$ supernatants of muscle, liver, and fibroblast homogenates solubilized with $1 \%$ Tween 20 in $500 \mathrm{mM} \mathrm{KCl}$ were preincubated for 60 min with IgG fraction (19) of preimmune or anti-CPT immune serum in $50 \mathrm{mM} \mathrm{KH}_{2} \mathrm{PO}_{4}, \mathrm{pH} 7.4,50 \mathrm{mM} \mathrm{NaCl}$, and $20 \mu \mathrm{L}$ of protein A Sepharose diluted with an equal vol of $10 \mathrm{mM}$ $\mathrm{KH}_{2} \mathrm{PO}_{4}$, pH 7.4 , at $25^{\circ} \mathrm{C}$. Then the mixture was centrifuged for $4 \mathrm{~min}$ and CPT activity was measured by assay III in the supernatant. 
Table 1. CPT activities of fibroblasts from patients with hepatic ( $A$ and $B$ ) and muscular (C and D) presentation*

\begin{tabular}{|c|c|c|c|c|c|c|}
\hline & & \multirow[b]{2}{*}{ Controls } & \multicolumn{4}{|c|}{ Patients } \\
\hline & & & $\mathrm{A}$ & B & $\mathrm{C}$ & $\mathrm{D}$ \\
\hline \multirow[t]{2}{*}{ Assay I } & & $\begin{array}{c}2.42 \pm 0.70 \\
(1.20-3.35) \\
(n=15)\end{array}$ & $0.39 \pm 0.04 \dagger$ & $0.56 \pm 0.18 \dagger$ & $1.35 \pm 0.20$ & $3.1 \pm 0.4$ \\
\hline & + Malonyl CoA $50 \mu \mathrm{M}$ & $\begin{array}{c}0.22 \pm 0.06 \\
(0.12-0.31) \\
(n=15)\end{array}$ & $0.21 \pm 0.05 \dagger$ & $0.26 \pm 0.03 \dagger$ & $0.15 \pm 0.02$ & $0.17 \pm 0.02$ \\
\hline Assay II & & $\begin{array}{c}2.20 \pm 0.35 \\
(n=7)\end{array}$ & $2.50 \pm 0.45 \dagger$ & $2.02 \pm 0.28 \dagger$ & $0.35 \pm 0.08$ & $0.31 \pm 0.06$ \\
\hline Assay III & & $\begin{array}{l}1.5 \pm 0.3 \\
(n=6)\end{array}$ & $1.5 \pm 0.15$ & $1.6 \pm 0.20$ & $0.28 \pm 0.03$ & $0.19 \pm 0.02$ \\
\hline
\end{tabular}

${ }^{*} \mathrm{CPT}$ activities were assayed by the measurement of palmitoyl-L-(methyl $\left.{ }^{14} \mathrm{C}\right)$ carnitine formation from palmitoyl CoA and L-(methyl $\left.{ }^{14} \mathrm{C}\right) \mathrm{carnitine}$ in three distinct assays as indicated in Materials and Methods. Assay I conducted in nondetergent conditions was performed on homogenate. Assays II and III, respectively, performed on homogenate preincubated with $1 \mathrm{mM}$ palmitoyl-D-carnitine and on $100000 \mathrm{~g}$ supernatant of fibroblasts solubilized with $1 \%$ Tween 20 in $0.5 \mathrm{M} \mathrm{KCl}$ were carried out in detergent conditions. Results (mean $\pm \mathrm{SD}$ ) are expressed as nmol of palmitoyl-L(methyl ${ }^{14} \mathrm{C}$ ) carnitine produced $\cdot \mathrm{min}^{-1} / \mathrm{mg}$ protein. $n=$ number of different control cell lines. Three independent experiments were performed in deficient strains. Range of control values is given in parentheses.

$\dagger$ Taken from Table 1 of Ref. 16.

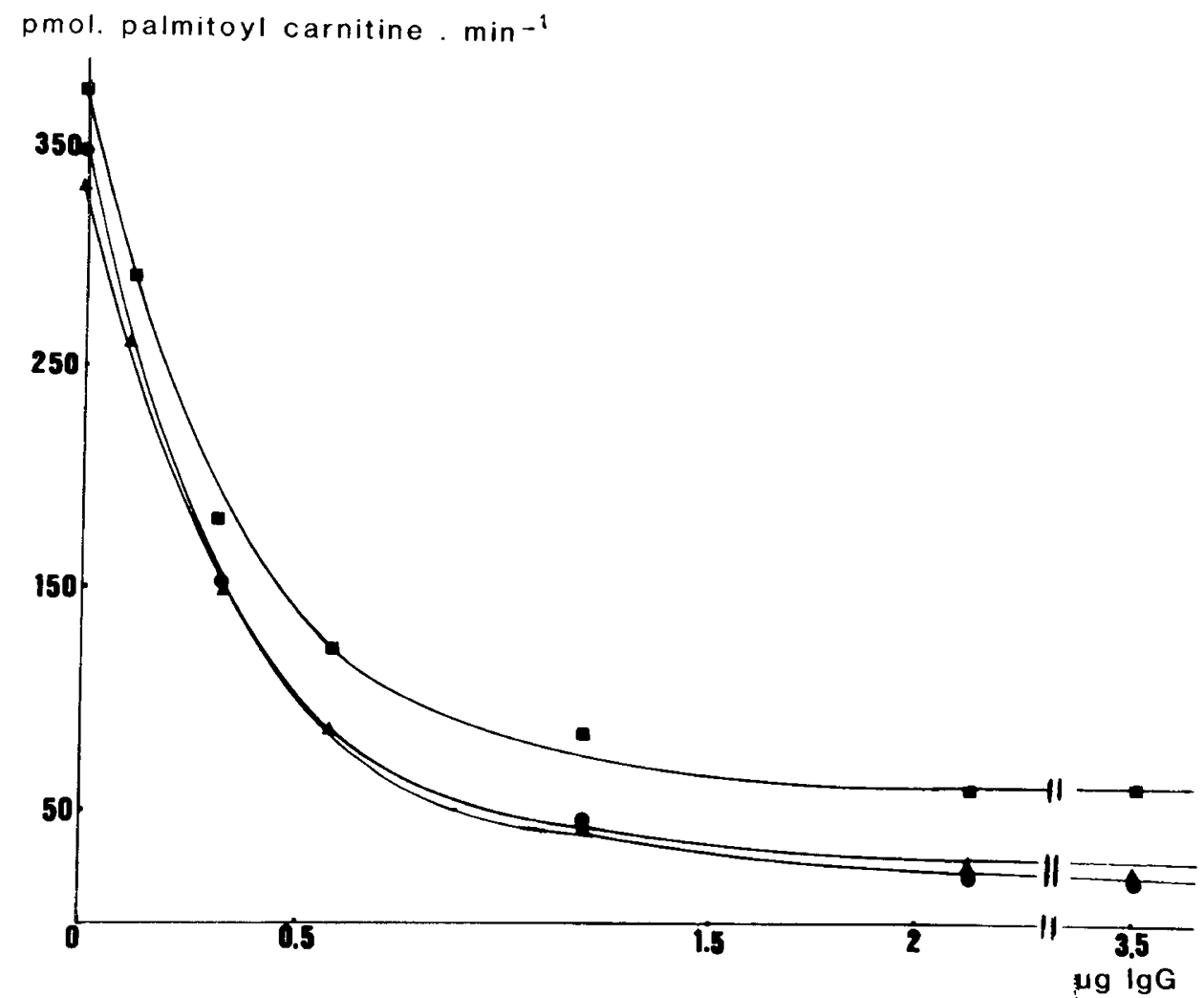

Fig. 1. Immunoinhibition of CPT activity from liver, fibroblasts, and skeletal muscle. Aliquots of $100000 \mathrm{~g}$ supernatants of liver ( $\square$ ), fibroblasts (•), and skeletal muscle (A) solubilized with $1 \%$ Tween 20 in $0.5 \mathrm{KCl}$ were incubated for $60 \mathrm{~min}$ at $25^{\circ} \mathrm{C}$ with various amounts of $\mathrm{gG}$ from antiCPT immune serum. Then the incubation mixtures were centrifuged at $12000 \times g$ for five min. CPT activity was measured in the supernatant. Incubation with nonimmune $\mathrm{IgG}$ did not affect CPT activity. Result of a typical experiment.

Immunoprecipitation experiments. Immunoprecipitation experiments were performed as described by Fenton et al. (20). $0.15 \mathrm{M} \mathrm{NaCl}, 10 \mathrm{mM}$ EDTA, $0.2 \% \mathrm{SDS}$, and $10 \mathrm{mM} \mathrm{KH}_{2} \mathrm{PO}_{4}$, $\mathrm{pH} 7.4$, were added to $100000 \mathrm{~g}$ supernatants of homogenates of muscle, liver, or fibroblasts, solubilized with $1 \%$ Tween 20 in $500 \mathrm{mM} \mathrm{NaCl}$. Aliquots (corresponding respectively to $300-500$ $\mu \mathrm{g}, 600-1200 \mu \mathrm{g}$, and $600-1200 \mu \mathrm{g}$ protein for liver, fibroblasts, and muscle), were then incubated with $0.5-2.0 \mu \mathrm{L}$ of preimmune or anti-CPT immune serum and $20 \mu \mathrm{L}$ of protein A Sepharose for $15 \mathrm{~h}$ at $4^{\circ} \mathrm{C}$. Pellets of protein A Sepharose were washed four times with $0.5 \mathrm{M} \mathrm{NaCl}, 10 \mathrm{mM}$ EDTA, $1 \%$ Tween $20,0.1 \%$ SDS, and $10 \mathrm{mM} \mathrm{KH} \mathrm{KH}_{4}, \mathrm{pH}$ 7.4. proteins bound to protein A Sepharose were released by incubation of the pellets for 10 min at $100^{\circ} \mathrm{C}$ with $50 \mu \mathrm{L}$ of $200 \mathrm{mM}$ Tris, $\mathrm{pH} 6.8$, containing $30 \%$ glycerol, $3 \%$ SDS, and $15 \% \beta$-mercaptoethanol; they were analyzed by SDS-PAGE carried out as described (21). Then proteins were electrotransferred to nitrocellulose sheets (22). Treatment and revelation were performed as described (23) with 


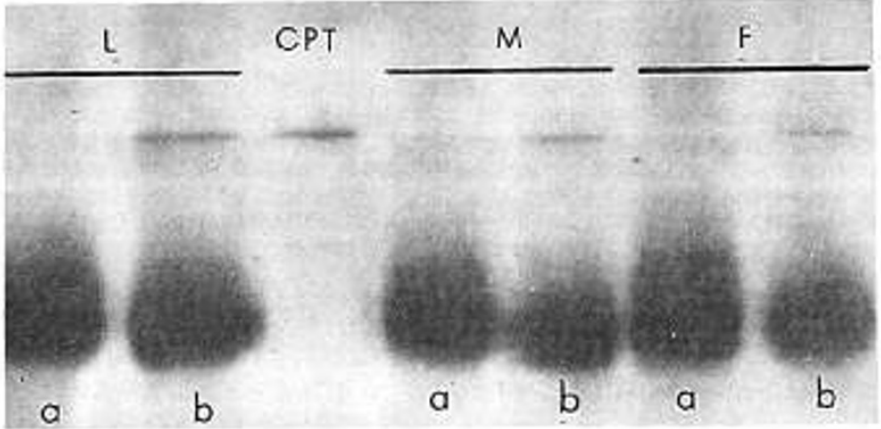

Fig. 2. Analysis of CPT of liver, fibroblasts, and skeletal muscle. Solubilized samples of liver $(L)$, skeletal muscle $(M)$, and fibroblasts $(F)$ were incubated for $15 \mathrm{~h}$ at $4^{\circ} \mathrm{C}$ with nonimmune $(a)$ or anti-CPT immune (b) serum and protein A Sepharose as described in Materials and Methods. Proteins bound to protein A Sepharose were then released and analyzed by SDS-PAGE and immunoblotting. Their electrophoretic mobility was compared to that of purified liver CPT. CPT activities (assay III) of samples incubated with preimmune or immune serum were, respectively, $4.0,1.25$, and $1.0 \mathrm{nmol} \cdot \mathrm{min}^{-1}$ in liver, skeletal muscle, and fibroblasts.
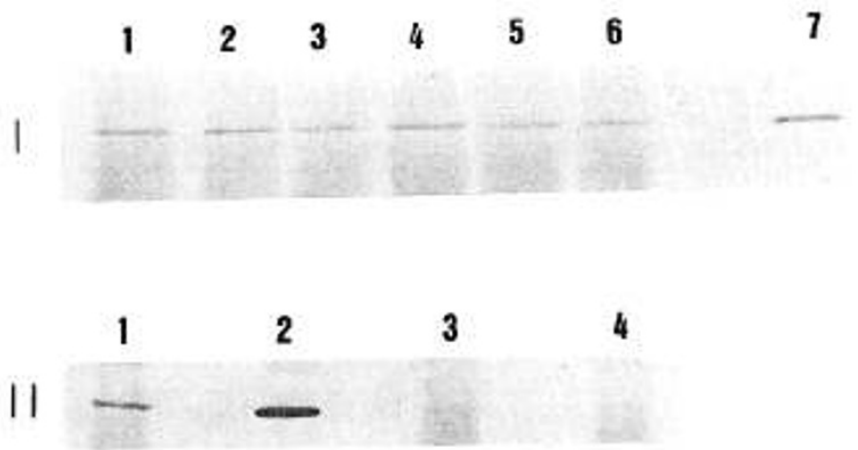

Fig. 3. Immunoquantitative analysis of $\mathrm{CPT}$ of fibroblasts from patients with CPT defects. Samples (1 mg protein) of solubilized fibroblasts from control cell lines and from patients with hepatic (patients A and B) and muscular (patients $C$ and D) forms of CPT defect were incubated with anti-CPT immune serum and protein A Sepharose as described in Materials and Methods. Proteins released from protein A Sepharose were analyzed by SDS-PAGE and immunoblotting. I: Experiments performed in duplicate. Lines 1 and 2, patient $\mathrm{A}$; lines 3 and 4, patient $\mathrm{B}$; lines 5 and 6 , control; line 7 , purified liver CPT $(0.5 \mu \mathrm{g})$. II: line 1, control; line 2, purified liver CPT $(1 \mu \mathrm{g})$; line 3, patient C; line 4, patient D. Similar results were obtained in two other separate experiments.

some modifications: nitrocellulose sheets were blocked $60 \mathrm{~min}$ at $37^{\circ} \mathrm{C}$ and $15 \mathrm{~h}$ at $4^{\circ} \mathrm{C}$. Then they were incubated for $60 \mathrm{~min}$ at $37^{\circ} \mathrm{C}$ and overnight at $4^{\circ} \mathrm{C}$ with a $1 / 200$ dilution of antiserum in the same buffer as for blocking. Protein was determined as described (24).

Palmitoyl CoA, L-carnitine, malonyl CoA and BSA fatty acidfree were purchased from Sigma Chemical Co. (St. Louis, MO), protein A Sepharose from Pharmacia, (Fine Chemicals, Piscataway, $\mathrm{NJ}), \mathrm{L}-\left(\right.$ methyl $\left.{ }^{14} \mathrm{C}\right)$ carnitine and ${ }^{35} \mathrm{~S}$-methionine from Amersham Corp. (Arlington Heights, IL), and palmitoyl-D-carnitine was a gift from Sigma Tau (Paris, France).

\section{RESULTS AND DISCUSSION}

CPT deficiency realizes two different clinical forms. Most patients with CPT defect exhibit muscular symptoms (acute episodes of rhabdomyolysis after prolonged exercise or occasionally after fasting), which are ascribed to muscular deficiency (14). Another clinical form of CPT deficiency (hepatic form) was diagnosed by Bougneres et al. (15). It consists of hypoglycemia with inappropriate ketonemia during fasting, resulting from he- patic CPT defect. Until now, only two patients have been diagnosed with this clinical form of CPT deficiency $(15,16)$. We studied (16) CPT activities of fibroblasts from two patients with the muscular form and the only two patients diagnosed with the hepatic form. We showed that CPTI was decreased in patients with the hepatic form, whereas it was normal and CPTII decreased in patients with the muscular form.

As shown in Table 1, study of CPT activities of fibroblast homogenates from two other patients with the muscular form of CPT defect gave the same figure. As compared with controls, these cell lines exhibited normal CPTI activity measured by assay $I$ performed in nondetergent conditions; the suppressibility of CPT activity by malonyl CoA, a specific inhibitor of CPTI (25), was similar in cell lines of controls and patients. CPT activity assayed in detergent conditions is considered to measure CPTII due to the suppressibility of CPTI by detergents $(6,7)$. Patients with $C$ and $D$ cell lines exhibited a decreased CPTII activity measured with assay II conducted without albumin and with 1 $\mathrm{mM}$ palmitoyl-D-carnitine as detergent (26). Similar results were obtained if the assay was performed with other detergents such as Tween 20 or Triton X100 (results not shown). A reduced CPT activity assayable in detergent conditions was also evidenced in the $100000 \mathrm{~g}$ supernatant of patients' fibroblasts solubilized with Tween 20 (assay III). These results strengthen the previous observation (16) that the muscular form of CPT deficiency may result from CPTII defect.

It must be stressed that mutations exhibited by the two sets of patients only affect CPTI activity in the hepatic form and CPTII activity in the muscular form. This result could suggest that CPTI and CPTII activities are borne by distinct proteins. Indeed, whether CPTI and CPTII are supported by a single or two different proteins is still discussed (8-13).

We previously purified, according to the procedures described by Fiol and Bieber (17), a protein supporting acylcarnitine transferase activity (Demaugre F, Cepanec C, Leroux JP, unpublished data) from human liver mitochondrial membranes solubilized with Triton X100. Antibodies against this protein were raised in rabbits. Its mol wt, estimated by SDS-PAGE, was $66000 \mathrm{D}$. It exhibits enzymatic activity (negligible with acetyl or butyryl CoA and maximal with lauryl $\mathrm{COA}$ as substrates) in presence of detergents. This protein likely supports CPTII activity (discussed below). As shown in Figure 1, IgG fraction of immune serum acts similarly on CPT activity measured in human liver, fibroblasts, and skeletal muscle solubilized with Tween 20; curves of suppression of CPT activity were similar in all tissues. In actual conditions of assay, more than $80 \%$ of CPT activity was suppressed at saturating concentration of Ig. Immunoprecipitation experiments followed by SDS-PAGE and Western blot were performed to analyze the material recognized by immune serum. As shown by Figure 2, immune serum recognized in liver, fibroblasts, and muscle a single protein of electrophoretic mobility similar to that of purified CPT. These data suggest that the protein supporting CPT activity assayable in extracts solubilized with detergents-presumably CPTII-is similar if not identical in these tissues. Similar findings concerning CPTII of rat liver and muscle were reported by Woeltje et al. (9).

Immunoprecipitation experiments (Fig. 3) were performed with fibroblasts from the two patients with the hepatic form and two patients with the muscular form of CPT deficiency. As compared with controls, immune serum recognized a single protein with normal electrophoretic mobility but in decreased amount in fibroblasts from patients with the muscular form of CPT deficiency. CRM estimated by densitometry was decreased by nearly $90 \%$ in cell line $C$ and by more than $95 \%$ in cell line D. The amount of CRM correlated with the residual CPTII activity. CPTI was unaffected in these cells. This result suggests that immune serum only recognizes the protein supporting CPTII activity. One can postulate that the CPTII defect of these cells results from a decreased production of protein with normal affinity for the antibody, although a decreased affinity for the 
antibody cannot be excluded. Studies in progress capable of probing the intimate structure of CPT genes and mRNA are required to differentiate these possibilities.

In fibroblasts from patients with the hepatic form of the defect, immunoprecipitation experiments did not reveal any difference between controls and patients (Fig. 3). Mutations causing the CPT defect exhibited by these cells (16; Table 1) do not affect the expression of the protein recognized by the immune serum, likely CPTII. The CRM of these cells does not correlate with the residual CPTI activity, but correlates with CPTII activity, which is unaffected.

The hypothesis of distinct proteins supporting CPTI and CPTII activities could explain results of enzymatic studies and immunoprecipitation experiments performed with both sets of patients. The mutations exhibited by "hepatic" and "muscular" cell lines would affect the expression of different proteins supporting CPTI and CPTII activities, respectively. Our results strengthen recent data advocating distinct proteins supporting CPT activities. Contrary to CPTII, CPTI activity is suppressed if assayed with detergents $(6,7,9)$. Antibodies raised against a purified protein supporting CPT activity assayable in detergent conditions do not recognize the protein supporting CPTI activity (9), identified by its capacity to bind tetradecylglycidyl $\mathrm{CoA}$, a specific inhibitor of CPTI activity. The mol wt of the protein supporting CPTI activity estimated either by SDS-PAGE (7) or by radiation inactivation experiments (8), was nearly $90000 \mathrm{D}$, whereas the mol wt of the protein bearing CPTII activity estimated by the same methods was nearly $70000 \mathrm{D}(7,8)$. As a consequence, CPT purified by classical methods using detergents (11-13, and Demaugre F, Cepanec C, Leroux JP, unpublished data) only supports CPTII activity. Moreover, it can be deduced from the data of Murthy and Pande (27) that proteins supporting CPTI and CPTII activities are not localized in the same subcellular structure: contrary to CPTII, CPTI activity might not be associated with the inner but with the external mitochondrial membrane.

As previously reported (28), the absence of membrane components may decrease CPTI activity. As a consequence, one cannot exclude that CPTI deficiency might be the result of mutations concerning such components. Further investigations must be performed to clarify this point.

Acknowledgment. The authors thank J. Kersual for the management of fibroblasts.

\section{REFERENCES}

1. McGarry JD, Foster DW 1980 Regulation of hepatic fatty acid oxidation and ketone body production. Annu Rev Biochem 49:395-420

2. Bremer J 1983 Carnitine-metabolism and functions. Physiol Rev 63:14201440

3. Declercq PE, Venicasa MD, Mills SE, Foster DW, McGarry JD 1985 Interaction of malonyl $\mathrm{CoA}$ and 2-tetradecylglycidyl $\mathrm{CoA}$ with mitochondrial carnitine palmitoyltransferase 1. J Biol Chem. 260:12516-12522

4. Bird MI, Munday LA, Saggerson ED, Clark JB 1985 Carnitine acyltransferase activities in rat brain mitochondria. Biochem $J$ 226:323-330

5. Brady LJ, Silverstein LJ, Hoppel CL, Brady PS 1985 Hepatic mitochondrial inner membrane properties and carnitine palmitoyltransferase $\mathrm{A}$ and $\mathrm{B}$. Biochem J 232:445-450

6. Lund H 1987 Carnitine palmitoyltransferase: characterization of a labile detergent extracted malonyl $\mathrm{COA}$ sensitive enzyme from rat liver mitochondria Biochim Biophys Acta 918:67-75

7. Declercq PE, Falck JR, Kuwajima M, Tyminski H, Foster DW, McGarry JD 1987 Characterization of the mitochondrial carnitine palmitoyltransferase enzyme system. I. Use of inhibitors. J Biol Chem 262:9812-9821

8. Zammit AV, Corstorphin CG, Kelliner MG 1988 Evidence for distinct functional molecular sizes of carnitine palmitoyltransferase I and II in rat liver mitochondria. Biochem J 250:415-420

9. Woeltje KF, Kuwajima M, Foster DW, McGarry JD 1987 Characterization of the mitochondrial carnitine palmitoyltransferase enzyme system. II. Use of detergents and antibodies. J Biol Chem 262:9822-9827

10. Kopec B, Fritz IB 1973 Comparison of properties of carnitine palmitoyltransferase II and preparation of antibodies to carnitine palmitoyltransferase. $J$ Biol Chem 248:4069-4074

11. Bergstrom JD, Reitz R 1980 Studies on carnitine palmitoyltransferase: the similar nature of CPTi (inner form) and CPTo (outer form). Arch Biochem Biophys 204:71-79

12. Clarke PR, Bieber LL 1981 Isolation and purification of mitochondrial carnitine octanoyltransferase activities from beef heart. J Biol Chem 256:98619868

13. Brady PS, Dunker AK, Brady LJ 1987 Characterization of hepatic carnitine palmitoyltransferase: use of bromoacyl derivatives and antibodies. Biochem J 241:751-757

14. Dimauro S, Trevisan C 1982 Carnitine palmitoyltransferase deficiency. In: Schotland DL (ed) Disorders of the Motor Unit. Wiley, New York, pp 657665

15. Bougneres PF, Saudubray JM, Marsac C, Bernard O, Odievre M, Girard J 1981 Fasting hypoglycemia resulting from hepatic carnitine palmitoyltransferase deficiency. J Pediatr 98:742-746

16. Demaugre F, Bonnefont JP, Mitchell G, Nguyen-Hoang N, Pelet A, Rimoldi M, Di Donato S, Saudubray JM 1988 Hepatic and muscular presentation of carnitine palmitoyltransferase deficiency: two distinct entities. Pediatr Res 24:308-312

17. Fiol PA, Bieber LL 1984 Sigmoid kinetics of purified beef heart mitochondrial carnitine palmitoyltransferase. J Biol Chem 259:13084-13088

18. Saudubray JM, Coude FX, Demaugre F, Johnson CC, Gibson KM, Nyhan WL 1982 Oxidation of fatty acid in cultured fibroblasts: a model system to the identification and study of defects in oxidation. Pediatr Res 16:877-881

19. Weatherill PJ, Kennedy SME, Burchell B 1980 Immunochemical comparison of UDP glucuronyltransferase from Gunn and Wistar rat livers. Biochem $\mathrm{J}$ 191:155-163

20. Fenton WA, Hack AM, Helfgott G, Rosenberg LE 1984 Biogenesis of the mitochondrial enzyme methylmalonyl CoA mutase. Synthesis and processing of a precursor in a cell free system and in cultured cells. J Biol Chem 259:6616-6621

21. Laemmli UK 1970 Cleavage of structural proteins during the assembly of the head of bacteriophage. Nature 227:690-695

22. Guengerich FP, Wang PP, Davidson MK 1982 Estimation of isozymes of microsomal cytochrome P-450 in rats, rabbits, and humans, using immunochemical staining coupled with sodium dodecyl sulfate-polyacrylamide gel electrophoresis. Biochemistry 21:1698-1706

23. Beaune PH, Flinois JP, Kiffel L, Kremers P, Leroux JP 1985 Purification of a new P-450 from human liver microsomes. Biochim Biophys Acta 840:364370

24. Lowry OH, Rosebrough NJ, Farr AL, Randall RJ 1951 Protein measurement with the folin phenol reagent. J Biol Chem 193:265-275

25. McGarry JD, Leatherman GF, Foster DW 1978 Carnitine palmitoyltransferase I. The site of inhibition of hepatic fatty acid oxidation by malonyl $\mathrm{COA}$. J Biol Chem 253:4128-4136

26. Bremer J, Norum KR 1967 The effects of detergents on palmitoyl CoA: carnitine transferase. J Biol Chem 242:1749-1755

27. Murthy MSR, Pande SV 1987 Malonyl CoA binding site and the overt carnitine palmitoyltransferase reside on the opposite sides of the outer mitochondrial membrane. Proc Natl Acad Sci USA 84:378-382

28. Sire P, Mangeney M, Montagne J, Nordmann R, Nordmann J 1983 Carnitine palmitoyltransferase I: inhibition by D-galactosamine and role of phospholipids. Eur J Biochem 136:371-375 